\title{
Anatomy and Histochemistry of Leaf and Stem of Brazilian Endemic Species Mollinedia clavigera Tul.
}

Isabel Christina Mignoni Homem ${ }^{1 *}$

https://orcid.org/0000-0002-8395-3258

Vanessa Barbosa Bobek ${ }^{1}$

https://orcid.org/0000-0002-2836-2076

Ellis Marina Szabo ${ }^{1}$

https://orcid.org/0000-0002-9075-9517

Jane Manfron Budel ${ }^{2}$

https://orcid.org/0000-0003-1873-2253

Vijayasankar Raman ${ }^{3}$

https://orcid.org/0000-0001-7368-9644

Vinicius Bednarczuk Oliveira1

https://orcid.org/0000-0001-7821-7742

\section{Obdulio Gomes Miguel ${ }^{1}$}

https://orcid.org/0000-0002-2231-9130

\begin{abstract}
${ }^{1}$ Federal University of Paraná, Pharmacy Department, Pharmaceutical Sciences Post-Grad Program, Curitiba, Paraná, Brazil; ${ }^{2}$ Ponta Grossa State University, Pharmacy Department, Pharmaceutical Sciences Post-Grad Program, Ponta Grossa, Paraná, Brazil; ${ }^{3}$ University of Mississipi, School of Pharmacy, National Center of Natural Products Research, Oxford, Mississipi, United States of America.
\end{abstract}

Received: 2019.06.24; Accepted: 2019.12.12.

*Correspondence: belmign@gmail.com; Tel.: +55-41-996797151

\section{HIGHLIGHTS}

- This is the first report of the microscopic study of Mollinedia clavigera

- Light microscopy, SEM, EDS and histochemistry analysis were made to support anatomical and chemical characteristics

- Non-glandular unicellular, long uniseriate, and short bifurcate trichomes were observed

- Prismatic crystals of calcium oxalate were observed on the surfaces of leaves

Abstract: This study aimed to investigate the anatomy and histochemistry of Mollinedia clavigera leaves and stems through photonic microscopy and scanning electron microscopy. Noteworthy features of leaves were: presence of paracytic stomata on both surfaces; simple as well as bifurcate non-glandular trichomes; prismatic calcium oxalate crystals; flat-convex midrib with a central and two dorsal bundles; concave-convex 
petiole with a single vascular bundle in open archh. Stems were cylindrical and showed prismatic and styloid crystals in the pith. Histochemical analysis detected lipophilic and phenolic compounds, starch grains and lignified elements such as brachysclereids and fibers. These features may assist in future identifications and quality control of $\mathrm{M}$. clavigera, avoid misidentification between other genus members, once species and genus studies are scarce.

Keywords: calcium oxalate crystals; microscopy; Monimiaceae; trichomes;

\section{INTRODUCTION}

Monimiaceae Juss. family comprises about 217 species. In Brazil, it is represented by 39 species, of which 35 are endemics. Species of Monimiaceae occur mainly in humid forests, such as the Atlantic Forest in the Brazilian biome. The genus Mollinedia Ruiz \& Pav. gathers about 50 species distributed from Southern Mexico to Southern Brazil, Paraguay and Bolivia. In Brazil, the genus is represented by 32 species, of which 29 are endemic [1]. The genus is reported to contain bezylisoquinoline alkaloids, phenylamides, steroids and essential oils [2]. Mollinedia genus presents several biological activities: to mention a few, antispasmodic activity was reported for M. schottiana (Spreng.) Perkins (syn. M. brasiliensis Schott ex Tul.) [3] and $M$. costaricensis Donn.Sm. showed antiarrhythmic activity [4].

In Brazil, M. clavigera Tul. is popularly known as 'capixim', 'pimenteira' or 'capixim-pimenteira', a bush which may reach 2 to 4 meters in hight. This species is endemic to southern and southeastern Brazil, occurring in higher altitudes of Atlantic Forest. It blooms in October and sets fruits during summer (December to March). The leaves are opposite, obovate to oblanceolate, coriaceous, acute at apex, narrowed at base and toothed along the margins. Stems are smooth and occasionally lenticellate [1]. Data on Mollinedia clavigera are scarce, specially on medicinal use and pharmacological activities, which are absent. A single study on chemical composition pointed flavonoids, alkaloids and essential oil in stems and leaves, saponins in stems, steroids and triterpens in leaves [5].

Micromorphological and anatomical features have been employed in the taxonomic evaluation of some plant species with important diagnostic values. Recently, taxonomic problems have been solved using microscopic features in several genus, including Baccharis [6,7], Eucalyptus [8], Lavandula [9], Mikania [10] and Piper [11].

Considering that few anatomical studies were performed in Mollinedia, this study aimed to analyze leaves and stems of $M$. clavigera to provide micromorphological and anatomical data which may assist taxonomic issues and proper identification of the species.

\section{MATERIAL AND METHODS}

\section{Plant material}

M. clavigera leaves and stems were collected in May 2015 in Curitiba, Paraná state of Brazil (Lat.: 25²6'52"S; Long.: 49¹4'21"W). The sample was identified by a taxonomist and deposited at the Municipal Botanical Museum of Curitiba, registered under the number MBM 38484. Authorization to access genetic heritage was granted by IBAMA (Process number 020001.001165/2013-47).

\section{Preparation of samples for light microscopy}

Samples were fixed in FAA 70 and stored in $70 \%$ ethanol solution [12,13]. Freehand transverse sections were cut using razors and double-stained in Basic Fuchsin and Astra Blue [14]. The sections were set on glass slides in a drop of glycerin solution (50\% in water) $[12,13]$. Sample slides were observed in Olympus CX31 microscope and photomicrographs were prepared using Olympus C-7070 digital camera attached to the microscope. 


\section{Histochemical analysis}

Histochemical tests were carried out using phloroglucin/ $\mathrm{HCl}$ to detect lignified elements [15], Sudan III for lipophilic substances [16], ferric chloride [12] and potassium dichromate [17] to detect presence of phenolic compounds and iodine solution (1\% in water) for staining starch [13].

\section{Scanning electron microscopy (SEM)}

The FAA-fixed samples were washed in water and immersed through a series of ethanol solutions $(80 \%$, $90 \%$ and $100 \%$ ). Then, samples were dried in a Balzers CPD 030 critical point dryer (BAL-TEC AG, Balzers, Liechtenstein) supplied with liquid $\mathrm{CO}_{2}$, coated with gold in a Balzers SCD 030 sputter coater and analyzed and imaged using a JSM 6360 LV scanning electron microscope (JEOL Ltd., Tokyo, Japan).

\section{RESULTS}

Leaf (Figure 1A) epidermis of Mollinedia clavigera, in surface view, shows straight and thin anticlinal cell walls on both sides (Figures $1 \mathrm{~B}$ and $\mathrm{C}$ ). This characteristic has also been observed in $M$. gilgiana Perkins and M. acutissima Perkins (syn. M. marliae Peixoto \& M.Pereira) [18]. Paracytic and anomocytic stomata are present on the abaxial side (Figure $1 \mathrm{C}$ ). These stomata types have also been previously reported for Monimiaceae species [19,20,21].
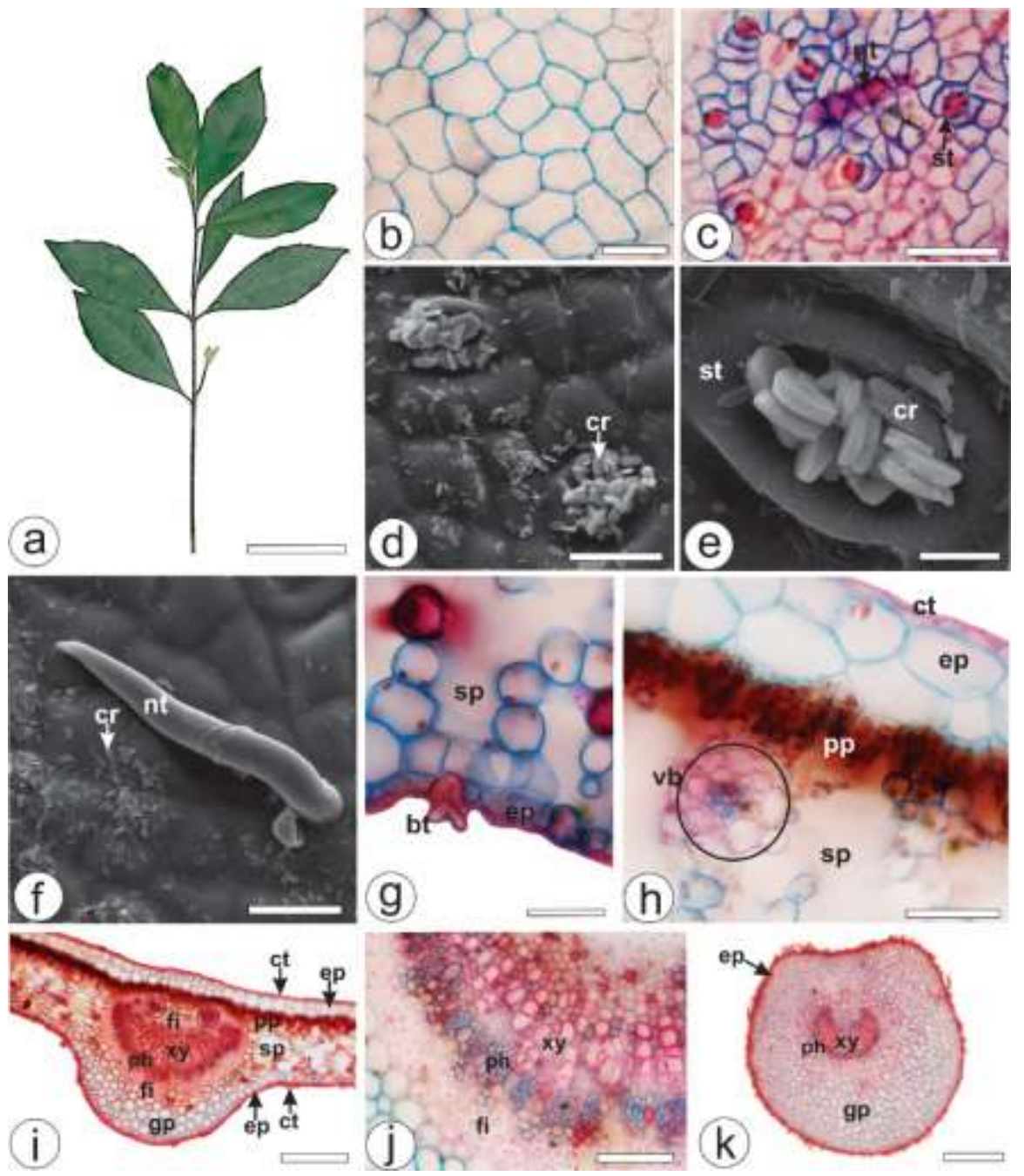

Figure 1. Morpho-anatomy of leaves of Mollinedia clavigera [b, c, g-k: light microscopy; d-f: SEM]. (a) A twig with leaves. (b-f) Leaf epidermis in surface view (b, f: adaxial side; c-e: abaxial). ( $g-k)$ Transverse sections of leaf blade ( $g, h)$, midrib (i, j) and petiole (k). [bt, bifurcate trichome; cr, crystal; ct, cuticle; ep, epidermis; fi, fiber; gp, ground parenchyma; $n$, non-glandular trichome; ph, phloem; pp, palisade parenchyma; pr, prismatic crystal; sp, spongy parenchyma; st, stomata; vb, vascular bundle; $x y, x y l e m]$. Scale bar: $a=5 \mathrm{~cm} ; \mathrm{i}, \mathrm{k}=300 \mu \mathrm{m} ; \mathrm{f}-\mathrm{h}, \mathrm{j}=50 \mu \mathrm{m} ; \mathrm{b}-\mathrm{d}=25 \mu \mathrm{m} ; \mathrm{e}=10 \mu \mathrm{m}$. 
Crystal sand and variously shaped crystals were observed externally on both surfaces of leaves (Figures 1D, E, F). Crystals are common in Mollinedia genus [21]. Nevertheless, the presence of crystals on the outer surfaces of leaves has not been previously reported in the genus. This feature is, however, observed in several other genus, including Eucalyptus [8] and Piper [11].

Two types of unicellular non-glandular trichomes, i) long and simple (Figure 1F) and ii) short and bifurcate (Figure 1g), are present in leaves. Unicellular trichomes with thick walls have been reported in several genera of Monimiaceae [21]. Mollinedia schottiana (Spreng.) Perkins presented similar trichomes, both types in petiole and short and bifurcate trichomes on leaf blade [18]. Features of trichomes and stomata are important anatomical markers and may assist in species identification as well as in the quality control of raw materials [22].

In leaf transverse section, uniseriate epidermis is covered by a thin and slighty striate cuticle on both surfaces (Figures 1G, H). A subepidermal layer in the adaxial side (Figure $1 \mathrm{H}$ ) presented cells larger than observed in epidermis. The presence of subepidermal layer has been reported for M. gilgiana and M. marliae [23]. An ontogenetic study of $M$. oligantha Perkins leaves reported that subepidermal layer is formed by periclinal divisions of protodermal cells leading to multi-layered epidermis [24].

The mesophyll is dorsiventral, formed by a layer of palisade parenchyma and up to eight strata of spongy parenchyma cells (Figures $1 \mathrm{H}, \mathrm{I}$ ). Small collateral vascular bundles enclosed by a parenchyma sheath are found immersed in the mesophyll (Figure $1 \mathrm{H}$ ). Dorsiventral mesophyll has been reported for species of Monimiaceae [21,23].

The midrib, in transection, is flat-convex. The epidermis, subepidermal and palisade layers are continued on adaxial side. Up to five layers of angular collenchyma are found on abaxial side (Figure 1I). The vascular system is represented by one collateral vascular bundle in open archh and 2 dorsal traces. A sclerenchyma ring encircles the vascular system (Figures $1 \mathrm{l}, \mathrm{J}$ ). Perivascular fibers have been reported for species of Mollinedia [18, 24].

The petiole, sectioned in middle region, is slightly concave-convex in outline (Figure 1K). Similar shape is also found in M. gilgiana [25]. The epidermis is uniseriate and covered externally by a thin cuticle. Short bifurcate non-glandular trichomes are present. The ground parenchyma occupies most part of the petiole and contain numerous phenolic idioblasts. Brachysclereids, solitary or in small groups, are observed dispersed in the ground parenchyma, which also have been observed in M. schottiana and M. marliae [18]. The vascular system is formed by a collateral vascular bundle arranged in open arch. In contrast, $M$. schottiana shows up to 12 collateral vascular bundles organized in open arch with invaginated ends [18].

Several prismatic crystals of varying sizes are found in the ground parenchyma and were identified as calcium oxalate by EDS (Figure 3). Calcium oxalate crystals are frequently found in species of Monimiaceae [21]. M. schottiana showed sand and polyhedral crystals in petioles and leaf blades [18], whereas M. marliae presented rhomboid crystals in the mesophyll [25]. 


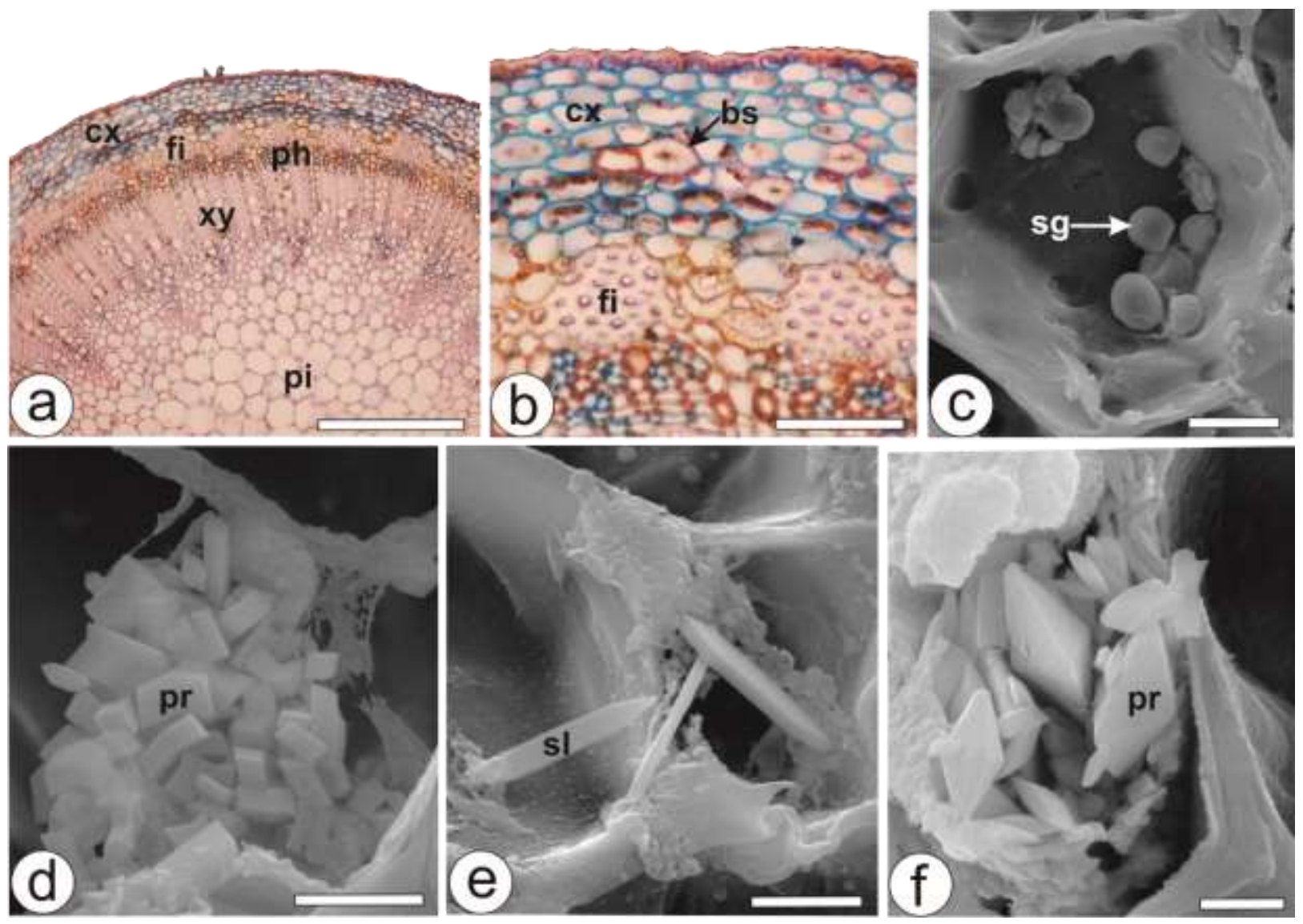

Figure 2. Stem anatomy of Mollinedia clavigera [a, b: light microscopy; c-f: SEM]. (a, b) Transverse sections of stem; (c) view of starch grains; (d-f) views of crystals [bs: brachysclereid; cx: cortex; fi: fibers; ph: phloem; pr: prismatic crystal; sl: styloid crystal; $x y$ : $x y l e m$; pi: pith]. Scale bar: $a=300 \mu \mathrm{m}, b=50 \mu \mathrm{m}, c=10 \mu \mathrm{m}, d, e=5 \mu \mathrm{m}, f=2 \mu \mathrm{m}$.

In transection, stem revealed a circular shape (Figure 2A). Epidermis is uniseriate and is covered by a thin cuticle. The cortex is formed by up to eight layers of parenchyma cells. Brachysclereids, isolated or in groups, are seen in the cortex. The endodermis, containing starch grains and prismatic crystals (Figure 2D), limits the cortex internally. The vascular cylinder presents phloem outward and xylem inward. Perivascular fiber caps and brachysclereids are adjoined to the phloem.

The pith is composed of parenchyma cells with thin walls (Figure $2 \mathrm{~A}$ ). Isolated and round starch grains are present (Figure 2C). Calcium oxalate crystals with prismatic shape (Figures 2D, F) and styloids with pointed ends (Figure 2E), as described above for mesophyll, midrib and petiole, are also found scattered in the stem. The EDS spectra showed that the chemical composition of the crystals is calcium oxalate. The Figure 4 shows prominent peaks for carbon $(23.14 \%)$, oxygen $(54.2 \%)$ and calcium $(22.66 \%)$ for the prismatic crystals. The major unlabeled peaks represent gold element used in coating the samples.

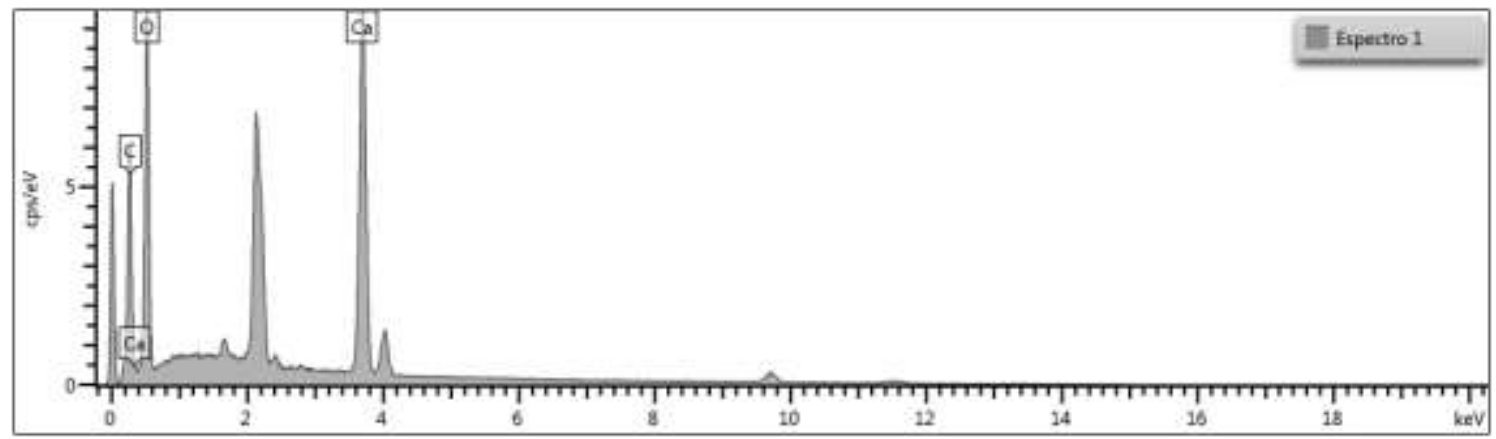

Figure 3. X-ray energy dispersive elemental analysis spectrum of an isolate prismatic crystal. 
The presence or absence of crystals and their type and chemical composition are useful in plant taxonomy. Calcium oxalate crystals occur in different forms and are found in specific tissues or organs in plants [26]. EDS technique can be used to determine crystals chemical composition [11,27] .

Lignification was detected in brachysclereids, perivascular fiber caps and xylem, using phloroglucinol/HCl test, in the midrib (Figures 4A, B), petiole and stem (Figure 4I). Idioblasts filled with phenolic compounds are found in spongy parenchyma and vascular bundles. These components reacted with ferric chloride (Figure 4F, G) and potassium dichromate solutions (Figure 4H). Species of Monimiaceae usually present alkaloids and flavonoids in leaves and roots [28]. Phenolic compounds have also been observed in M. gilgiana and M. marliae [23]. Phenolic substances have been extensively studied for their useful properties, such as antimicrobial, antioxidant [29], antiherbivore and allelopathic [30]. Starch grains react positively with iodine solution. Small and rounded grains were observed in aggregates of two or more granules, located in petiole's ground parenchyma (Figure 4D), stem's endodermis and pith (Figure 2C).

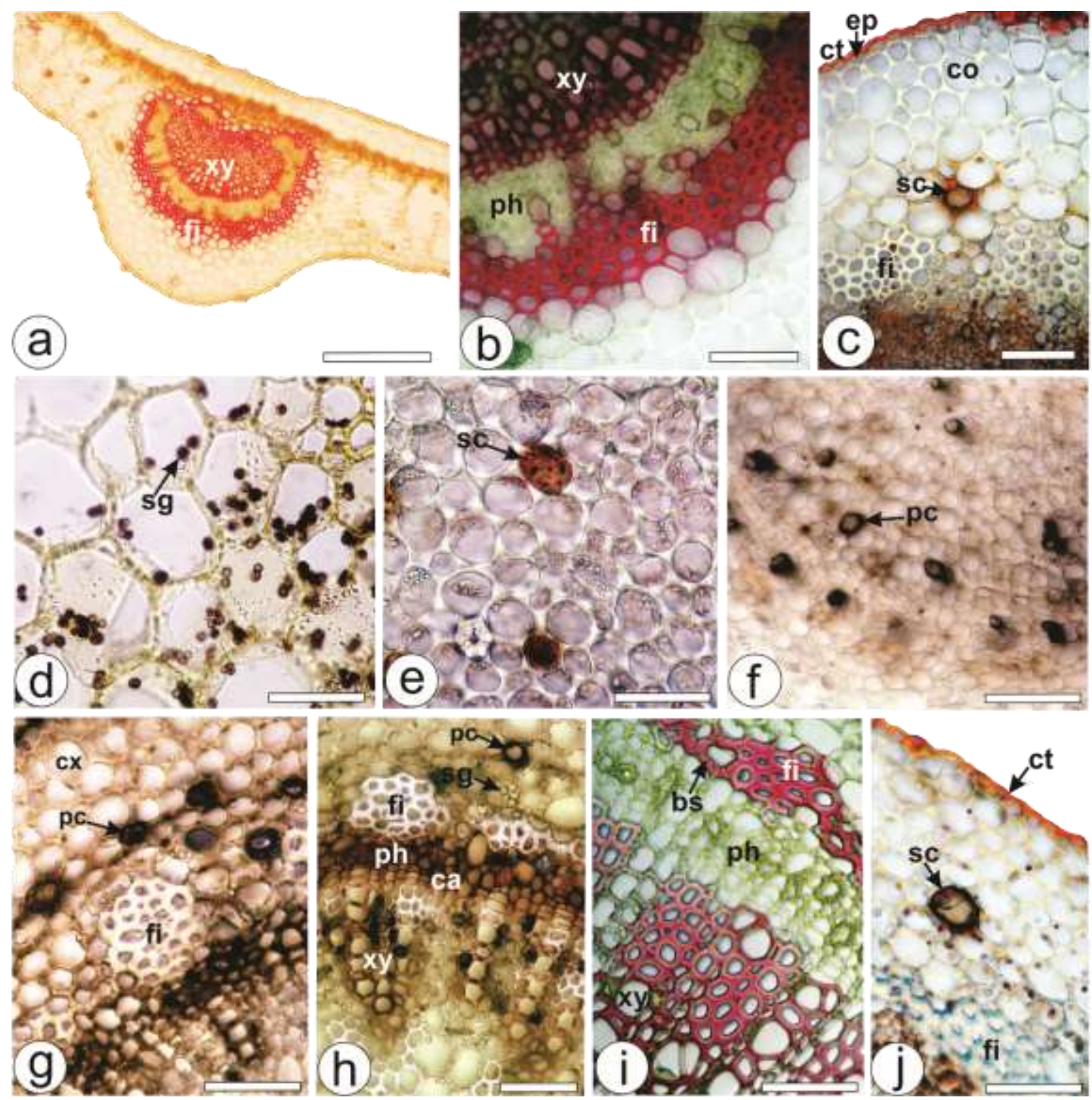

Figure 4. Histochemistry of Mollinedia clavigera [a, b, i: stained in phloroglucinol/HCl; c, e, j: Sudan III; c, d: iodine solution (1\%); $\mathrm{f}$, g: ferric chloride; h: potassium dichromate solution (10\%)]. Transverse sections a-c: midrib; $\mathrm{d}$, e: petiole; f-j: stem [bs: brachysclereid; ca: cambium; co, collenchyma; ct, cuticle; cx: cortex; en, endodermis; ep, epidermis; fi, fiber; gp, ground parenchyma; pc, phenolic compounds; ph, phloem; pi, pith; pc: phenolic compound; sc, secretory cell; sg, starch grains; $x y, x y l e m]$. Scale bar: $a=200 \mu \mathrm{m}, b-j=50 \mu \mathrm{m}$. 
Oil droplets were found within the secretory cells in the midrib (Figure $2 \mathrm{C}$ ), ground parenchyma of petiole (Figure 2E) and cortex of the stem (Figure 2J). Secretory cells are frequently found in epidermis and mesophyll of Monimiaceae species [21], such as Macropeplus dentatus (Perkins) I. Santos \& Peixoto and $M$. ligustrinus (Tul.) Perkins [31]. The presence or absence of oil cells may assist in species identification [32].

\section{CONCLUSION}

The present work revealed important anatomical characteristics which may be employed in identification of Mollinedia clavigera. The noteworthy features include hypostomatic leaves with paracytic and anomocytic stomata; two types of non-glandular unicellular trichomes: long uniseriate, and short bifurcate trichomes; prismatic crystals on leaf surfaces; presence of subepidermal layer on the adaxial side; flat-convex midrib with one vascular bundle in open arch and two dorsal bundles; concave-convex petiole with one vascular bundle in open arch; cylindrical stem; and the presence of prismatic and styloid crystals in the stem pith. Histochemical analysis confirmed the presence of lipophilic and phenolic compounds, starch grains and lignified elements such as brachysclereids and fibers.

Funding: "This research was funded by Coordenação de Aperfeiçoamento de Pessoal de Nível Superior - Brasil (CAPES), grant number 001".

Conflicts of Interest: The authors declare no conflict of interest. The funders had no role in the design of the study; in the collection, analyses, or interpretation of data; in the writing of the manuscript, or in the decision to publish the results.

\section{REFERENCES}

1. Lirio EJ, Peixoto AL, Pignal M. Monimiaceae in Flora do Brasil 2020 em construção. Jardim Botânico do Rio de Janeiro. 2018 Available from: <http://floradobrasil.jbrj.gov.br/reflora/floradobrasil/FB10070>.

2. Murillo E, Lombo O, Mendez, JJ. Química y Funcionalidad Biológica de Mollinedia racemosa (Monimiaceae). Inf Tecnol. 2011;22: 3 - 14.

3. Leitão GG, Simas NK, Soares, SSV, Brito APP, Claros BMG, Brito TBM, et al. Chemistry and pharmacology of Monimiaceae: a special focus on Siparuna and Mollinedia. J Ethnopharmacol. 1999;65:87-102.

4. Lopez JA, Lin FT, Duah FK., Aly Y, Schiff Jr PL. Mollinedine, a new alkaloid from Mollinedia costarricensis. J Nat Prod. 1988; 51: 754-9.

5. Homem ICM, Szabo EM, Miguel OG. Mollinedia clavigera Tul. (Monimiaceae) Phytochemical screening and leaves', steams' and essential oil's physical-chemical parameters determination. Visão Acadêmica. 2015; 16: 3040.

6. Budel JM, Raman V, Monteiro LM, Almeida VP, Bobek VB, Heiden G, et al. Foliar anatomy and microscopy of six Brazilian species of Baccharis (Astereraceae). Microsc ResTech. 2018; 81: 832-42.

7. Budel JM, Duarte MR, Macro and microscopic characters of the aerial vegetative organs of Carqueja: Baccharis usterii Heering. Braz. arch. biol. technol. 2010; 53: 123-31.

8. Migacz IP, Raeski PA, Almeida VP, Raman V, Nisgoski S, Muniz GIB, et al. Comparative leaf morpho-anatomy of six species of Eucalyptus cultivated in Brazil. Rev Bras Farmacogn. 2018; 28: 273-81.

9. Justus B, Almeida VP, Gonçalves MM, Assunção DPSF, Borsato DM, Arana AFMontenegro. Chemical composition and biological activities of the essential oil and anatomical markers of Lavandula dentata L. cultivated in Brazil. Braz. Arch. Biol. Technol

10. Almeida VP, Hirt AA, Raeski PA, Mika BE, Justus B, Santos VLP, et al. Comparative morphoanatomical analysis of Mikania species Rev Bras Farmacogn. 2017; 27: 9-19.

11. Bertocco ARP, Migcaz IP, Santos VLP, Franco CRC, Silva RZ, Yunes RA, et al. Microscopic diagnosis of the leaf and stem of Piper solmsianum C.DC. Microsc ResTech. 2017; 80: 831-7.

12. Johansen DA. Plant microtechnique. New York: McGraw-Hill Book; 1940.

13. Berlyn GP, Miksche JP. Botanical microtechnique and cytochemistry. Ames: lowa State University; 1976.

14. O'Brien TP, Feder N, McCull ME. Polychromatic staining of plant cell walls by toluidine blue-O. Protoplasma, 1964; 59: 364-73.

15. Sass JE. Botanical microtechnique. Ames: lowa State College Press; 1951.

16. Foster AS. Practical plant anatomy. Princeton: D. Van Nostrand; 1949.

17. Gabe M. Techniques histologiques. Paris: Masson \& Cie; 1968. 
18. Batalha, AP. Anatomia e perfil lignoidico do lenho e das folhas de Mollinedia schottiana (Spreng.) Perkins. Dissertação. Universidade Federal Rural do Rio de Janeiro. Instituto de florestas. 109f. 2005.

19. Solereder H. Systematic Anatomy of the Dicotyledons. Oxford: Clarendon Press; 1908.

20. Money LL, Bailey IW, Swamy BGL. The morphology and relationships of the Monimiaceae. J Arnold Arbor, 1950; 31: 371- 403.

21. Metcalfe CR, Chalk L. Anatomy of the dicotyledons. Magnoliales, Illiciales, and Laurales. Oxford: Claredon Press; 1987.

22. Guerreiro KK, Bobek VB, Santos VLP, Franco CRC, Paula JP, Farago PV, et al. Análise farmacobotânica de folha e caule de Tanacetum vulgare (L.). Rev Bras PI Med, 2015; 18: 89-95.

23. Barros CF, Callado CH, Da Cunha M, Costa CG, Pugialli HRP, Marquete O, et al. Anatomia ecológica e micromorfologia foliar de espécies de floresta montana na reserva ecológica de Macaé de Cima. In: Lima, H.C. and Guedes Bruni, R. R (Eds.). Serra de Macaé de Cima: Diversidade Florística e Conservação em Mata Atlântica. Rio de Janeiro, Jardim Botânico do Rio de Janeiro; 1997; 275-296.

24. Callado CH, Freitas MHV, Lima HRP, Costa CG. Diferenciação da epiderme múltipla da lâmina foliar de Mollinedia oligantha Perkins. Floresta e Ambient. 2006; 12: 75-78.

25. Callado CH, Pugialli HRL, Costa CG, Cunha M, Marquete O, Barros CF. Anatomia do lenho de espécies da Mata Atlântica: Interpretação ecológica e indicações para aproveitamento.In: Lima HC and Guedes-Bruni R. R (Eds), Serra de Macaé de Cima: Diversidade Florística e Conservação em Mata Atlântica. Rio de Janeiro, Jardim Botânico do Rio de Janeiro; 1997. p. 251-273.

26. Meriç Ç. Calcium oxalate crystals in some species of the Tribe Inuleae (Asteraceae). Acta Biol Cracov Seri Bot. 2009; 51: 105-110.

27. Saulle CC, Raman V, Oliveira AVG, Maia BHLNS, Meneghetti EK., Flores TB, et al. Anatomy and volatile oil chemistry of Eucalyptus saligna cultivated in South Brazil. Rev Bras Farmacogn. 2018; 28: 125-134.

28. Moreira DL, Leitão GG. Quantitative Determination of Liriodenine and Moupinamide in Five Species of Mollinedia by High Performance Liquid Chromatography. Phytochem Anal. 2001; 12: 223 - 225.

29. Garg D, Shaikh A, Muley A, Marar T. In-vitro antioxidant activity and phytochemical analysis in extracts of Hibiscus rosa-sinensis stem and leaves. Free Radicals and Antioxidants, 2012; 2: 41- 46.

30. Larcher, W. Ecofisiologia vegetal. São Carlos: Rima, 531p. 2000.

31. Costa FF, Lima, HRP, Cunha M, Santos IS. Leaf Anatomy and histochemistry of Macropeplus dentatus (Perkins) I.Santos \& Peixoto and Macropeplus ligustrinus (Tul.) Perkins (Monimiaceae). Acta bot bras. 2010; 24: 852-861. Marques CA, Leitão GG, Bizzo HR, Peixoto AL, Vieira RC. Anatomia e análise de óleo essencial das folhas de Hennecartia omphalandra J. Poisson (Monimiaceae). Rev Bras Farmacogn. 2009; 19: 95 - 105.

(C) 2020 by the authors. Submitted for possible open access publication under the terms and conditions of the Creative Commons Attribution (CC BY NC) license (https://creativecommons.org/licenses/by-nc/4.0/). 